\title{
TAX TREATMENT OF COVENANTS NOT TO COMPETE: A PROBLEM OF PURCHASE PRICE ALLOCATION*
}

Conflicting tax interests of the vendor and vendee of a going business influence the amount of purchase price allocated to goodwill rather than to an accompanying covenant not to compete. ${ }^{1}$ Embracing reputation. and customer loyalty, goodwill ${ }^{2}$ may rest largely on the owner's individual personality or skill and, after sale of the business, its retention may therefore depend upon the purchaser obtaining a promise from the seller not to open a competing business. ${ }^{3}$ Since an excess of purchase price over the value of all tangible and

*Richard Ullman, 29 T.C. 129 (1957).

1. In addition to the physical assets, the purchaser of a going business generally acquires goodwill, which may be an important source of earning power. When goodwill is based primarily on general reputation of the business rather than personal qualities of the proprietor, the purchaser ordinarily has little difficulty obtaining the benefits of the firm's good name. Many customers may, however, be attracted by an individual proprietor and will not necessarily patronize his successor. Frequently, the purchaser's ability to retain the seller's goodwill depends upon the seller's withdrawal from competition; accordingly, the seller's covenant not to compete often accompanies the sale of a personalized business. See, generally, 6 CoRbin, Contracts $\$ 1385$ (1951) ; Carpenter, Validity of Covenants Not To Compcte, 76 U. PA. L. Rev. 244 (1928) ; Taylor, Covenants Not To Compete: Consulting Arrangements, Adjustments to Purchase Price, N.Y.U. 12TH INST. oN FED. TAx. 1047 (1954).

2. "The good-will, which has been the subject of sale, is nothing more than the probability, that the old customers will resort to the old place." Lord Eldon in Cruttwell v. Lye, 17 Ves. Jun. 335, 346, 34 Eng. Rep. 129, 134 (Ch. 1810). This definition, taken from the earliest reported judicial pronouncement on goodwill, has been expanded to include any competitive advantage which attaches to a particular business and is transferable. See Yang, Goonwill and Other Intangribles 21-26, 28 (1927) ; Raby, Good Will on Changing From a Corporate to Noncorporate Form, 30 TAxes 623, 624 (1952). The basic acknowledged concepts of goodwill are industrial goodwill (harmonious labor relations), financial goodwill (ability to obtain credit and venture capital), and consumer goodwill. See Yang, op. cit. stupra at 26-37, 47-56; Note, 62 Yale L.J. 640, 640-41 n.1 (1953). Consumer goodwill includes favorable customer attitudes, general reputation, customer lists, prospective patronage and symbols invoking consumer response. See Note, An Inquiry Into the Nature of Goodwill, 53 CoLumr. L. REv. 660, 664-65 \& nn.5-8 (1953) (hereinafter cited as Inمuiry Into Goodwild) ; cf. Berman, Valuation of Anmities, Business Interests, Copyrights, Good IVill, Life Insurance Policies, Patents, Trade Marks and Trust Interests for Federal Tax Purposes, 58 Dick. L. Rev. 58 (1953). Some major sources of consumer goodwill include type of service, established connections, quality of goods and location. See YaNG, op. cit. supra at 41-45. On goodwill generally, see LEAKE, CoMmerctal GoodwinL (4th ed. 1948) ; Moore, Legal Protection of Goodwill (1936); Inguiry Into GoodwILI.

3. Covenants not to compete have accompanied transfers of the following types of business. Accounting Practice: Estate of Masquelette v. Commissioner, 239 F.2d 322 (5th Cir. 1956); Jacques L. Ach, P-H 1954 T.C. Mem. Dec. I 54349; Richard S. Wyler, 14 T.C. 1251 (1950) ; Rodney B. Horton, 13 T.C. 143 (1949). Bakery: D \& H Bagel Bakery, Inc., P-H 1955 T.C. Mem. Dec. If 55100. Dry Cleaning: Andrew Newman, Inc., P-H 1957 T.C. Mem. Dec. If 57224. Insurance Agency: Dauksch v. Busey, 125 F. Supp. 
identifiable intangible assets must be attributed either to goodwill or the covenant, ${ }^{4}$ pricing the covenant is primarily a task of apportionment between it and goodwill rather than of valuing the covenant alone. ${ }^{5}$ The vendor, seeking capital gains, will demand a high price for goodwill-a capital asset -and a correspondingly low price for the covenant-taxable as ordinary income. ${ }^{7}$ The vendee, on the other hand, prefers a high basis for the covenant ${ }^{s}$ which, unlike goodwill, has a limited life furnishing depreciation deductions. ${ }^{9}$

130 (S.D. Ohio 1954) ; Lloyd H. Walker, P-H 1954 T.C. Mem. Dec. I 54177; R. Bryson Jones, 17 B.T.A. 1213 (1929). Laundry and Linen Service: Joseph Faulkner, P-H 1956 T.C. Mem. Dec. I 56039; Aaron Michaels, 12 T.C. 17 (1949). Newspaper Publishing: Commissioner v. Gazette Tel. Co., 209 F.2d 926 (10th Cir. 1954); Toledo Blade Co. v. Commissioner, 180 F.2d 357 (6th Cir.), cert. denied, 340 U.S. S11 (1950); George H. Payne, 22 T.C. 526 (1954). Radio Station: Radio Medford, Inc. v. United States, 150 F. Supp. 641 (D. Ore. 1957). Restaurant: Sidney Alper, P-H 1956 T.C. Mem. Dec. \56271; J. S. L. Restaurants, Inc., P-H 1951 T.C. Mem. Dec. If 51056. Tissue Products: Frances Silberman, 22 T.C. 1240 (1954).

4. Goodwill represents that part of the value of a business which cannot be allocated elsewhere. It may be measured by capitalizing the excess of the business's profits over a normal return from the tangible and identifiable intangible assets. See FinNEY \& MIILLER, PRINCIPLES of AcCounting-Intermediate 496-97 (4th ed. 1951) (hereinafter cited as Finney \& MTrLeR); INQuiry INTo Goodwill 677-79. This usual accounting definition of goodwill provides a quantitative measure of the worth of the business's qualitative goodwill. See note 2 supra. Although the exact amount varies with the individuals concerned, a "normal" return is defined as "the amount which would attract proprietorship capital equal to the agreed valuation of the net assets other than goodwill." FINNEY \& MIrLLER 502. Identifiable intangible assets may include franchises, patents, copyrights, leases and trademarks. See YANG, op. cit. sutpra note 2, at 57-86. For pertinent considerations in capitalizing and computing excess value to determine goodwill, see FinNEY \& MIILER 497-502.

5. The price paid for a business will represent the value of its identifiable assets plus goodwill. See note 4 supra. Hence, when a covenant not to compete accompanies the purchase, the parties can raise or lower the value placed on the covenant by allocating corresponding amounts to goodwill. Cf. Rodney B. Horton, 13 T.C. 143, 148 (1949).

6. "Good will is a capital asset and any gains resulting from the sale thereof are capital gains." Id. at 149. See Aaron Michaels, 12 T.C. 17, 19 (1949).

7. See, e.g., Hamlin's Trust v. Commissioner, 209 F.2d 761 (10th Cir. 1954).

If the vendor were to sell his stock at a loss, he would still attempt to minimize the amount allocated to the covenant against which he cannot offset his capital loss. Only if the vendor's annual taxable income were less than $\$ 1,000$ for the taxable year and the five succeeding years would he be indifferent to treatment accorded the covenant. See Iwr. REv. CODE OF 1954, $\S \S 1211,1212$. The same reasoning holds true for a sole proprietor selling at a loss except that if sale of his $\$ 1231$. assets results in a net loss on those assets, he would be indifferent to receiving ordinary income on his covenant because it will be offset by the ordinary loss attributed to his $\$ 1231$ assets. See INT. REv. CoDE of 1954, $\$ 1231$. In the economic situation in which sale at a loss occurs, a covenant not to compete may well be unnecessary.

8. See Commissioner v. Gazette Tel. Co., 209 F.2d 926 (10th Cir. 1954) (covenant one fourth of total sales price); Dauksch v. Busey, 125 F. Supp. 130 (S.D. Ohio 1954) (two thirds) ; Andrew Newman, Inc., P-H 1957 T.C. Mem. Dec. If 57224 (three fifths); J. S. L. Restaurants, Inc., P-H 1951 T.C. Mem. Dec. If 51056 (five eighths); Toledo Blade Co., 11 T.C. 1079 (1948), aff'd, 180 F.2d 357 (6th Cir.), cert. denied, 340 U.S. $\$ 11$ 
Similarly, when an incorporated business is transferred through sale of corporate stock, goodwill represents that part of the stock's value not allocable to any specific asset. ${ }^{10} \mathrm{~A}$ low price on a selling shareholder's covenant will therefore permit a high allocation to the stock with attendant capital gains for the vendor-shareholder. ${ }^{11}$ Because stock is nondepreciable ${ }^{12}$ and resale ordinarily is not contemplated, the vendee, obtaining no immediate tax benefit from a high basis for stock, will prefer a large allocation to the depreciable covenant. ${ }^{13}$ In any event, whatever the price agreed upon when a business is transferred through sale of stock, inclusion of a separate covenant from the selling shareholder automatically deprives him of capital gains to the extent of the price of the covenant. ${ }^{14}$

(1950) (approximately eight ninths) ; Carboloy Co., P-H 1943 T.C. Mem. Dec. If 43325 (at least ten elevenths) ; Eitington-Schild Co., 21 B.T.A. 1163 (1931.) (approximately one half).

9. See, e.g., Commissioner v. Gazette Tel. Co., supra note 8; 4 MERTENs, FeDERAL Iricome TAxATION $\$ 23.68$ (rev, ed. 1954) (collecting cases) (hereinafter cited as MIERTENS).

A large allocation to the covenant is necessary for the vendee to avoid having a large outlay tied up in goodwill, the useful life of which cannot be estimated with sufficient certainty to justify depreciation. See, e.g., Red Wing Malting Co. v. Willcuts, 15 F.2d 626, 632-33 (Sth Cir. 1926), cert. denied, 273 U.S. 763 (1927); cf. Clarke v. Haberle Crystal Springs Brewing Co., 280 U.S. 384 (1930). No deduction for depreciation is allowable with respect to goodwill. Bittrer, Federal Income Estate and GifT TaXaTION 276-77 nn. 1,2 (1955). Depreciation deductions for goodwill are disallowed because of difficulty in determining when and to what extent they become exhausted in use. See 4 Mertens $\$ 23.10$, at 23-24 n.46 (collecting cases) ; Inquiry Into Goodwill 725. This rule has been severely criticized and depreciation deductions advocated whenever the life of the business and/or the goodwill is ascertainable. See Clarke v. Haberle Crystal Springs Brewing Co., supra (brewery's existence was to be terminated due to Prohibition Act; goodwill deduction disallowed). Moreover some elements of goodwill may have a determinable, exhaustible life and should be depreciable. See Axrerican Institute of Accountants, Restatenient and Revision of Accounting Research Bulletins $37-39$ (1953). Since goodwill is measured by capitalization of excess profits, see note 4 supra, many accountants feel that purchased goodwill should be amortizable over the period in which excess profits will result from the vendor's management, see FINNEY \& MIILER 506-07; Paton, Advanced Accounting 409-10 (1947). For arguments favoring and disfavoring depreciable goodwill, see Dodd \& BAKER, Corporations 1101-03 (2d ed. 1951) (collecting citations).

10. See Finney \& Miller, Prunciples of Accounting-Advanced 335 (4th ed. 1952).

11. If the taxpayer is not a dealer in securities and his shares of stock are not held for sale to customers in the ordinary course of business, his stock constitutes a capital asset. Rev. Rul. 56-153, 1956-1 Cunr. Bull. 166, 168-69. See also Hamlin's Trust v. Commissioner, 209 F.2d 761, 762 (10th Cir. 1954), affirming 19 T.C. 718 (1953); Abraham L. Berman, P-H 1955 T.C. Mem. Dec. \I 551.13.

12. See note 11 supra. Stock could not be a capital asset if it were depreciable. Int. REv. CODE OF 1954, § 1221 (2).

13. See note 8 supra.

14. See, e.g., Helvering v. Salvage, 297 U.S. 106 (1936) ; Hamlin's Trust v. Commissioner, 209 F.2d 761 (10th Cir. 1954) ; Cox v. Helvering, 71 F.2d 987 (D.C. Cir. 1934); of. Beal's Estate v. Commissioner, 82 F.2d 268 (2d Cir. 1936). But see Sidney Alper, 
In Richard Ullman, ${ }^{15}$ this dilemma confronted the joint owners of three corporations who, on selling their stock, executed seven-year covenants not to compete. ${ }^{16}$ After agreeing to $\$ 1,000,000$ as the total purchase price, the vendee suggested allocating $\$ 400,000$ to the covenants. ${ }^{17}$ The vendors, fearful of losing the sale, agreed to an apportionment of $\$ 350,000$ to the covenants and $\$ 650,000$ to the cost of the stock. ${ }^{18}$ When capital gains treatment was sought for the full $\$ 1,000,000$, the Tax Court held the $\$ 350,000$ ordinary income on two grounds. That the covenant was separately bargained for was considered evidence of its severability from goodwill. ${ }^{19}$ In addition, the court postulated that stockholders cannot own corporate goodwill and concluded that proceeds from the sale of a shareholder's-as distinguished from a sole proprietor's-covenant cannot be income from the sale of goodwill but only compensation for personal services, taxable as ordinary income. ${ }^{20}$

Under present law, each of the two grounds on which Ullman rests is insufficient in itself to support the result. The fact that stockholders have no direct proprietary interest in corporate goodwill does not, standing alone, make the covenant price ordinary income; in the absence of a stated allocation to stock and covenant, courts have attributed the entire purchase price to the stock, taxable at capital gains rates. ${ }^{21}$ Nor does mere agreement by the parties on a separate price for the covenant, without more, produce ordinary income taxation. ${ }^{22}$ And since failure to $\mathrm{fx}$ a price may result in a judicially determined covenant value taxed as ordinary income, ${ }^{23}$ neither inclusion nor omis-

P-H 1956 T.C. Mem. Dec. If 56271 (court ignored contractual allocation on ground that covenant had not been separately dealt with by parties) ; George H. Payne, 22 T.C. 526 (1954) (court refused to consider document specifying allocation because not signed and agreed upon by all parties).

15. 29 T.C. 129 (1957).

16. Id. at $135-36$.

17. $I d$. at 133 .

18. Ibid.

19. Id. at 139-40. Courts often equate the concept of a covenant severable from goodwill with a separately bargained for covenant. See, e.g., George H. Payne, 22 T.C. 526, 531-32 (1954) ; Aaron Michaels, 12 T.C. 17, 19 (1949). For cases indicating the contrary, i.e., that a separately bargained for covenant may be part of goodwill, see note 22 infra.

20. 29 T.C. at $139-40$.

21. Sidney Alper, P-H 1956 T.C. Mem. Dec. đI 56271 (despite allocation, covenant ignored as not separately bargained for because necessary to assure transfer of goodwill; no mention of stockholder status). George H. Payne, 22 T.C. 526 (1954) (allocation in unsigned memorandum but not in formal contract; covenant not separately bargained for held nonseverable from goodwill; no mention of stockholders lacking direct proprietary interest).

22. Taylor, supra note 1, at 1060-61 (1954); see Toledo Newspaper Co., 2 T.C. 794 (1943) (despite agreement, capital gains treatment accorded entire profit after comparing selling price with cost of entire assets, tangible and intangible, taken as a whole); see also Joseph Faulkner, P-H 1956 T.C. Mem. Dec. If 56039 (covenant nonseverable from assets transferred); $c f$. Sidney Alper, supra note 21 (covenant "in consideration of" stated figure nonetheless not separately bargained for).

23. See Rodney B. Horton, 13 T.C. 143 (1949) (goodwill and covenant held severable). Courts have often held the covenant severable and permitted a vendee deprecia- 
sion of a covenant price by the parties has alone been the determining factor in prior case law. Apparently unwilling to break new ground, the Ullman court conformed with previous decisions by relying both on its finding that the covenant was specially bargained for and on the status of taxpayers as shareholder-vendors rather than proprietors. ${ }^{24}$

The Tax Court's distinction between proprietors and shareholders ignores the actual function and effect of a covenant not to compete. The covenant enables the vendee to acquire those customers who presumably will do business with him so long as the covenantor does not become a competitor. ${ }^{25}$ Reputation and customer loyalty being elements of goodwill, ${ }^{26}$ the covenant is a means of protecting goodwill transferred with the business ${ }^{27}$ and is enforceable only if adopted for that purpose. ${ }^{28}$ Since goodwill can be equally protected whether the covenant is that of a proprietor, stockholder or key employee, differences arising from status are differences not in the operation of the covenant but in the ease with which its value is ascertained. ${ }^{29}$ In an arm's length transaction, the price allocated to an employee's covenant-which protects goodwill sold by another-is automatically taxed as ordinary income, for the price can only reflect the value of the covenant, the taxpayer having conveyed nothing else. ${ }^{30}$ In contrast, the proprietor-vendor's covenant maintains transferred goodwill which he owned directly, while the promise of the shareholder-vendor conserves

tion deductions when no allocation was made by the parties. Wilson Athletic Goods Mfg. Co. v. Commissioner, 222 F.2d 355 (7th Cir. 1955) (lack of express segregation by parties not binding) ; Frances Silberman, 22 T.C. 1240 (1954) (business had no goodwill) ; B. T. Babbitt, Inc., 32 B.T.A. 693 (1935) (other assets had little value; primary purpose of vendee was elimination of competition); see Christensen Mach. Co. v. United States, 73 Ct. C1. 149, 50 F.2d 282 (1931) (excess over fair value of purchased stock depreciable). More often, however, courts have accepted the absence of allocation as evidence of nonseverability and disallowed depreciation deductions. Radio Medford, Inc. v. United States, 150 F. Supp. 641 (D. Ore. 1957) (parties did not treat covenant having little value as distinct item) ; Dauksch v. Busey, 125 F. Supp. 130, 133 (S.D. Ohio 1954) (parties did not treat covenant separately from goodwill); D \& H Bagel Bakery, Inc., P-H 1955 T.C. Mem. Dec. If 55100 (covenant included only to guarantee goodwill); Lloyd H. Walker, P-H 1954 T.C. Mem. Dec. If 54177 (covenant inserted only to protect other intangibles); Jacques L. Ach, P-H 1954 T.C. Mem. Dec. If 54349 (impossible to segregate covenant from goodwill); Harold J. Burke, 18 T.C. 77 (1952) (covenant intended to protect purchase of business); R. Bryson Jones, 17 B.T.A. 1213 (1929) (vendee purchased no intangible asset other than goodwill); Market Supply Co., 3 B.T.A. 841 (1926) (impossible to separate consideration).

24. For previous cases resting on the same dual grounds as Ullman, see note 14 supra.

25. See note 1 supra.

26. See note 2 supra.

27. See INQUiRY InTo GoodwILl 716-19.

28. A covenant not to compete is unenforceable as against public policy if intended for purposes other than protecting goodwill. 6 CoRBIN, Contracts $\S 1387$ (1951) (collecting cases); 5 Williston, Contracts $\$ 1641$ (rev. ed. 1937) (collecting cases); see Carpenter, Validity of Contracts Not To Compete, 76 U. PA. L. Rev. 244 (1928).

29. See InQuiry Into Goodwill 716-19.

30. See Estate of Mildred K. Hyde, 42 B.T.A. 738 (1940); Kaplan, Agreement Not To Compete-Tax Consequences, 58 DiCK. L. REv. 387, 389 (1954). 
purchased stock-value flowing from goodwill. Thus, the close relation of the proprietor or shareholder covenant to goodwill makes a price apportionment between them difficult. ${ }^{31}$ Irrespective of the covenantor's identity or of complexity in allocation, however, the covenant always fulfills precisely the same function of safeguarding goodwill-without altering the essential nature of either goodwill or the covenant.

Accordingly, a covenant with a separately stated price should always produce ordinary income to the extent of that price regardless of the status of the covenantor. Although a sale of property-goodwill-accompanies the covenant, the covenant itself is not property and therefore not a capital asset, but a promise of certain conduct supported by consideration. ${ }^{32}$ Moreover, ordinary income treatment for the covenant would create no special hardship. Favorable tax rates accorded capital gains are intended to mitigate the burden of telescoping into one year gain resulting from appreciation in value over many years and to preserve liquidity for those capital items whose transfer might be unduly discouraged by heavy taxation. ${ }^{33}$ But a taxpayer wishing to sell a business, besides being likely to have a reason for the transfer which outweighs the inhibiting high taxation of incidental covenants, ${ }^{34}$ can mitigate the harsh effects of

31. See, e.g., Jacques L. Ach, P-H 1954 T.C. Mem. Dec. If 54349; Market Supply Co., 3 B.T.A. 841,843 (1926).

32. A capital asset, the sale or exchange of which results in capital gains or losses, must be "property." INT. REv. CODE oF 1954, § 1221. Capital gain may also be derived from certain assets other than those capital assets defined by $\S 1221$; but these other assets, including real property used in taxpayer's trade or business and depreciable property identically used, must also be "property." Id. § 1231.

Congress did not define "income" in the 1954 Code but stated that "gross income means all income from whatever source derived ...." Id. $\$ 61$ (a). No doubt exists that proceeds from a contract, other than for a sale of capital assets or $\$ 1231$ assets, constitute ordinary income under this broad statement. Covenants not to compete, when unaccompanied by, or separable from, a sale of other assets, have consistently been held to be compensation for services, taxable as ordinary income under present $\S 61$ (a) (1). See, e.g., Beals' Estate v. Commissioner, 82 F.2d 268, 270 (2d Cir. 1936). However, the covenant becomes depreciable property in the hands of the vendee and, on sale of the business by the vendee, proceeds from the sale of the covenant would probably be taxed as capital gains. See INT. Rev. CoDE of 1954, § 1231.

33. See Magill, Taxable Income 115 (rev. ed. 1945) ; New York Stock Exchange, Taxes, Equity Capital, and Our Economic Challenges 38-40 (1953). Present tax treatment of capital gains has been criticized on two grounds: the capital gains provisions do not accomplish their intended goals, and the goals themselves are not desirable. Lowndes, The Taxation of Capital Gains and Losses Under the Federal Income Tax, 26 Texas L. Rev. 440 (1948) ; Miller, The "Capital Asset" Concept: A Critique of Capital Gains Taxation, 59 YALE L.J. 837, 1057 (1950). See 3B MERTENS $\$ 22.01$, at 5-8 n.3 (collecting citations).

34. For nontax motives inducing sale, see Estate of Masquelette v. Commissioner, 239 F.2d 322, 323 (5th Cir. 1956) (lack of time to devote to accounting practice); Richard Ullman, 29 T.C. 129, 131 (1957) (ill health and bickering among owners) ; Lee Ruwitch, 22 T.C. 1053, 1054 (1954) (finding employment elsewhere); Richard Wyler, 14 T.C. 1251, 1253 (1950) (ill health); Toledo Newspaper Co., 2 T.C. 794, 799 (1943) (declining profits) ; Christensen Mach. Co. v. United States, 73 Ct. Cl. 149, 50 F.2d 282 (1931) (disagreement among owners). 
telescoping by arranging to receive compensation for noncompetition in installments over the life of the covenant. ${ }^{35}$ Such an arrangement should be satisfactory to the vendee, who would make a smaller initial outlay while retaining the ability to stop payments on breach of the covenant. The vendor, on the other hand, might be apprehensive of vendee insolvency or simply prefer immediate payment. ${ }^{36}$ Unwillingness to assume ordinary commercial risks, however, is an unpersuasive reason for conferring capital gains advantages on payments for nonperformance of activity which, if performed, would produce ordinary income. ${ }^{37}$ Furthermore, capital gains rates would remain applicable to the stock of selling shareholders ${ }^{38}$ and to transferred business assets other than inventory and accounts receivable. ${ }^{39}$

35. Whether the vendor is on the cash or accrual accounting basis, the covenant could easily be worded so that his right to the yearly payment depends on his not having competed that year; the vendee's obligation would not become enforceable until that time. See 2 MERTENs $\$ \$ 10.04,12.61$. Six-year proration of a lump sum payment could have been achieved under INT. REv. CODE OF 1954, $\S 452$, but this section was retroactively repealed by Act of June 15, 1955, c. 143, $\$ 1,69$ Stat. 134. The Senate Finance Committee expected to report out new legislation concerning prepaid income, but none has been forthcoming. S. REP. No. 372, 84th Cong., 1st Sess. 6 (1955). For a discussion of $\S 452$, see Wagman, Sections 452 and 462: Stormy Past but a Bright Tomorroze, 33 TAXES 711 (1955).

36. A lump sum capital gain may still receive better tax treatment than ordinary income spread over the years. For a taxpayer filing a joint return, application of the maximum capital gains rate of $25 \%$ to a lump sum payment results in lower tax than the application of ordinary rates to yearly taxable income exceeding $\$ 18,000$. See INT. REv. Code of 1954, \$§ 1(a), 1201, 1202.

37. See note 32 supra.

38. See note 11 supra. Prior to sale, a stockholder-vendor might covenant not to compete with his corporation for a nominal consideration. This would raise the value of the stock transferred to include the value of the covenant. On selling his stock, the vendor would then receive the same amount for the stock as he would have received for the stock plus a personal covenant. Thus, the price of the covenant becomes part of the price of stock yielding capital gain to the vendor. The vendee, however, may dislike this arrangement because he receives no depreciation deductions. See note 9 supra. And the courts may well look through form to the substance of the transaction, especially if the shareholder covenant to the corporation was executed solely for tax-avoidance purposes. See Commissioner v. Court Holding Co., 324 U.S. 331, 334 (1945); Gregory v. Helvering, 293 U.S. 465,470 (1935).

To abtain a direct proprietary interest in business goodwill, the vendor might decide to liquidate the corporation immediately prior to sale. Such liquidation would be treated like a sale of stock-producing all capital gain. INT. REv. CoDE of 1954, § 331. If sale to the vendee accurs within one year after a plan of liquidation is adopted, the corporation will not recognize any gain or loss on the sale. Id. $\$ 337$. And the vendor, if he sells the assets immediately, receives no gain on the sale to vendee because his basis for the property would presumably be the same as the sales price, i.e., fair market value. Id. $\S 335$ (a). (The vendor would not elect to postpone recognition of gain under $\$ 333$ since he plans on selling immediately.) But the vendee may not be satisfied with the allocations to the different assets. Moreover, if business were heavily dependent on personal qualities of the stockholder, courts might hold that no goodwill was transferred to the stockholder upon liquidation. M. M. Gordon, P-H 1950 T.C. Mem. Dec. If 50061 (business continued 
Taxing the covenant as ordinary income and honoring the contracting parties' price allocation would achieve predictability of tax treatment in an area currently marked by needless uncertainty. ${ }^{40}$ Since vendor and vendee ordinarily bargain with their net position after taxes in mind, the proposed rule would avoid unnecessary disappointment of their legitimate expectations ${ }^{41}$

after liquidation as partnership by the former stockholders; no goodwill transferred because business depended on personal attributes of the stockholders); Ruth M. Cullen, 14 T.C. 368 (1950). But see Estate of Ben R. Henderson, P-H 1952 T.C. Mem. Dec. II 52301 (ignoring personal attributes of shareholder turned sole proprietor).

If the corporation were to sell its assets to the vendee with no plan of liquidation, or after one year from the date of the plan, the stockholder's covenant would bring him personal income. See, e.g., Toledo Newspaper Co., 2 T.C. 794, 805 (1943). If the vendor is a corporation selling assets of a subsidiary after liquidation, no gain or loss would be recognized to the parent on liquidation. INT. Rev. CoDE of 1954, § 332. But on selling the assets, the parent would recognize gain or loss and would ordinarily take the subsidiary's basis for the liquidated assets, $i d . \S 334$ (b) (1), unless the purchase of the subsidiary was within two years of sale, thus activating the adjusted basis of the subsidiary's stock, id. \$334(b) (2). With either basis, the parent corporation, upon selling the assets to the vendee, would be taxed as a sole proprietor selling his business. The covenant, if no price is allocated to it, may therefore be transformed into capital gain, but the corporation would receive ordinary income on the sale of inventory and accounts receivable.

39. See INT. Rev. Code of 1954, §§ 1221 (1), 1221 (4).

40. At present, no clearly defined standard exists by which vendors and vendees can predict tax treatment accorded a covenant not to compete. Compare Richard Ullman, 29 T.C. 129 (1958) (stockholder-vendor ineligible for capital gains treatment of covenant), with George H. Payne, 22 T.C. 526 (1954) (stockholder-vendor's covenant accorded capital gains). Compare Hamlin's Trust v. Commissioner, 209 F.2d 761 (10th Cir. 1954) (a1location a ground for taxation of covenant as ordinary income), with Toledo Newspaper Co., 2 T.C. 794 (1943) (despite allocation, covenant found nonseverable from goodwill and taxed as capital gains). Compare Estate of Masquelette v. Commissioner, 239 F.2d 322 (5th Cir. 1956) (absence of allocation a ground for giving capital gains), with Rodney B. Horton, 13 T.C. 143 (1949) (despite failure to allocate, covenant found severable from goodwill and taxed as ordinary income). Compare Andrew Newman, Inc., P-H 1957 T.C. Mem. Dec. If 57224 (allocation evidence that covenant is independent of goodwill; vendee may depreciate), with Toledo Blade Co. v. Commissioner, 180 F.2d 357 (6th Cir.), cert. denied, 340 U.S. 811 (1950) (despite allocation, covenant indistinguishable from goodwill; vendee may not depreciate). Compare Radio Medford, Inc. v. United States, 150 F. Supp. 641 (D. Ore. 1957) (failure to allocate a ground for denying vendee right to depreciate), with Wilson Athletic Goods Mfg. Co. v. Commissioner, 222 F.2d 355 (7th Cir. 1955) (despite failure to allocate, covenant had independent value; vendee may depreciate).

Attempts to base tax treatment on the relation between covenant and goodwill necessarily produce unpredictability because of the vagueness of the standard. Compare Estate of Masquelette v. Commissioner, supra, with Rodney B. Horton, supra. More frequently than not, however, if the vendor was under compulsion to sell and the covenant seems to be of little value, courts treat the covenant as nonseverable from goodwill and allow capital gains treatment. See Estate of Masquelette v. Commissioner, supra; Lee Ruwitch, 22 T.C. 1053 (1954) ; Richard Wyler, 14 T.C. 1251 (1950) ; Toledo Newspaper Co., supra.

41. For articles suggesting ways for vendors and vendees to work within the present framework, see Maddrea, Both Buyer and Seller Face Tax Traps in Covenants Not To Compete, $6 \mathrm{~J}$. TAXation 86, 87 (1957) (to insure depreciation for vendee, allocation should not be out of line with other assets or with income) ; Taylor, Covenants Not To Compete: 
while saving the Commissioner the difficult task of attempting to apportion between covenant and goodwill or stock. ${ }^{42}$ Thus, Ullman is to be commended for confirming the principle that allocation by stockholder-vendors results in ordinary income for the stipulated price of the covenant. ${ }^{43}$ In simultaneously basing the decision on the vendor's shareholder status, however, the court supplied inconsistent criteria for cases involving either shareholder-vendors with an unallocated price or nonshareholder-vendors with an allocated figure. Specifically, the court's reliance on allocation contradicts prior nonshareholder cases ignoring an allocation $; 4$ and the court's statement that a stockholdervendor cannot receive capital gains for a covenant conflicts with previous nonallocation cases according capital gains treatment to shareholders. ${ }^{45}$ Ullman therefore lays the ground for later decisions to hold that stipulated allocations do not reflect true values or, in the opposite situation, that failure to allocate must be remedied by judicial apportionment. ${ }^{40}$

Had the Ullman court viewed allocation by the parties as the sole determining factor, future vendors and vendees irrespective of status would know the tax consequences of covenants and could plan accordingly. Moreover, tax revenue would not be significantly impaired by failure to allocate or by allocations not reflecting true values. No price for the covenant, or an understated one, though increasing the proportion of capital gains for the vendor, reduces de-

Consulting Arrangements, Adjustments to Purchase Price, N.Y.U. 12TH INST. ON FED. TAx. 1047, 1063 (1954) (vendee should employ vendor on a consulting arrangement and make covenant incident thereto). See also Kamens \& Ancier, Tax Consequences of a Coventant Not To Compete, 27 TAxes 891 (1949); Kaplan, supra note 30; McCandless, Tax Consequences of Covenants Not To Compete, N.Y.U. 8TH INST. oN FED. TAX. 880, 888 (1950).

42. No exception should be made to the proposed rule. Assuming the vendor is aware of the tax consequences accorded a covenant not to compete, this element is one of many considered in negotiations looking to maximum gain after taxes. Thus, the vendor might receive a higher total price in exchange for the tax concession he made on the covenant. Excessive time and money would be lost if the Commissioner attempted to do more than ascertain that the negotiations were conducted at arm's length. A hard case is presented by the vendor who did not plan on competing, was ignorant of the tax consequences of allocation, and was forced to allocate by a vendee with stronger bargaining power. Such cases are likely to be too infrequent, however, to justify making an exception which would invite litigation by taxpayers seeking to take advantage of indefinite judicial precedent. Furthermore, government revenues should not be impaired to give special capital gains treatment to people receiving poor tax advice. Similarly, if the vendee were ignorant of tax consequences, and the unallocated covenant had a provable value, an exception in his favor should be denied. But see Comment, S STAN. L. REv. 485, 492-93 (1956) (arguing that vendee should be allowed to depreciate covenant if he can prove its value, even in absence of allocation).

43. See note 14 supra.

44. See cases cited note 22 supra.

45. See cases cited note 21 supra.

46. For cases in which the courts did not follow the stipulated allocations but instead placed their own values on the covenants in question, see note 22 supra. For a case in which the court allocated after the parties had failed to do so, see Rodney B. Horton, 13 T.C. 143 (1949). 
preciation deductions available to the vendee. Conversely, excessive depreciation deductions produced by undue allocation to the covenant are balanced by the increased amount of ordinary income received by the vendor. ${ }^{47}$ While parties in different tax brackets may achieve an overall tax saving by careful allocation, potential revenue loss does not appear great enough to justify expenditures for investigation and litigation on the question of true value. ${ }^{48}$

47. See text at notes 7-13 supra.

48. For instance, application of ordinary income rates to the vendor may increase his tax by an amount greater than the benefit the vendee would receive by depreciation deductions. In this case, the vendor may be able to obtain a zero allocation to the covenant by lowering the price enough to compensate the vendee for his lost deductions. But the government's revenue loss through the lower tax on the vendor will be in large part restored through the inability of the vendee to obtain depreciation deductions. A vendee may benefit from depreciation deductions in an amount greater than the vendor would save by getting capital gains instead of ordinary income. The vendee may then pay a higher price to compensate the vendor for his higher tax. Again, the higher price and ordinary income treatment for the vendor will restore most of the revenue lost through excessive vendee depreciation deductions. 